LINBO LI, Ph.D. ${ }^{1}$

E-mail: 1linbo@tongji.edu.cn

MENGFEI CAO, Ph.D. Candidate ${ }^{1}$

E-mail: caomengfei@tongji.edu.cn

JIAJUN YIN, Master ${ }^{1}$

E-mail: 250061168@qq.com

YANLI WANG, Ph.D. ${ }^{1}$

(Corresponding author)

E-mail: wangyanli@tongji.edu.cn

YAHUA ZHANG, Ph.D. ${ }^{2}$

E-mail: yahua.zhang@usq.edu.au

${ }^{1}$ Key Laboratory of Road and Traffic Engineering

of Ministry of Education

College of Transportation Engineering

Tongji University

No. 4800 Cao'an Road, Jiading District, Shanghai

201804, China

${ }^{2}$ School of Commerce

University of Southern Queensland

Toowoomba, Queensland, Australia
Traffic Planning

Original Scientific Paper

Submitted: 17 Jan. 2020

Accepted: 18 May 2020

\title{
SPATIAL DISTRIBUTION OF TRAVEL ACTIVITIES AND ITS RELATIONSHIP WITH POINTS OF INTEREST
}

\begin{abstract}
This study explores the spatial distribution characteristics of travel activities and their relationship with land use, using data from the resident travel survey in 2015 of Xiaoshan District of Hangzhou City, China. A new classification method is proposed to classify the travel activity patterns into three groups: single-activity travel, multi-activity intermittent travel, and multi-activity continuous travel. The main findings are: (a) the length of activity chain and the proportion of multi-activity travels increase with the distance between residence and activity centre; (b) the non-home destinations of single-activity travel, multi-activity intermittent travel and multi-activity continuous travel agglomerate towards the activity centre, and the degree of agglomeration increases in this order; (c) the distribution density of Point Of Interest (POI) and activity destinations have strong positive correlations in space; (d) some attributes of POIs and demographics have significant influence on multi-activity continuous travels. These findings are useful in inducing the activities through reasonable combinations and spatial interconnections of POIs in urban planning.
\end{abstract}

\section{KEYWORDS}

urban planning; travel activity; land use; spatial distribution; multi-activity travel; point of interest layout.

\section{INTRODUCTION}

With the improvement in the standard of living and rapid urban development in China, out-of-home activities of residents have become more diversified and decentralized. However, most activities need to be finished within one day, which can produce tremendous travel demand leading to traffic congestions and environmental pollution, especially in large cities. These problems have worsened in recent years with the increased car ownership as more and more ordinary households can afford to buy cars. In addition, traffic safety is another issue that cannot be ignored with the popularity of cars, which is significant, influenced by complex driver behaviours $[1,2]$. Traffic congestion, air-quality deterioration and road accidents could be alleviated by increasing the market share of public transportation, improving the level of traffic demand management, and optimizing the land use pattern and transit-oriented development [3]. For example, residents usually have one or more activities in a day, and these activities are distributed in different places. If land use can be optimized to cluster these activities into one or limited destinations, and if public transportation can be used to connect these destinations, private car travels will be greatly reduced, which will 
contribute to sustainable urban development and the construction of environmentally friendly cities. The functional structure of the cities has been largely concerned and dealt with in the urban development process. Pacione has been studying this topic over the years, mainly focused on the land use and urban structure changes in the developed cities, and researched quality of life and urban environment from a geographical perspective [4-6]. In the last decade, many studies have examined the relationship between the built environment and travel behaviours in the Chinese cities [7]. However, questions such as how out-of-home activity destinations are distributed in urban space and how these activities can be clustered, receive little attention and remain largely unanswered.

The influence of land use on travel behaviour has been extensively studied. In general, the built environment, socio-demographics and attitudes are found to be the key factors influencing the car ownership and use. In particular, Wang and Cao [8] found that the impacts of built environment on the individuals' activity-travel behaviour are different among different socio-demographic groups, and that neighbourhood planning can affect the influence. Jiang et al. [9] pointed out that a strategic urban planning favouring bus rapid transit development, mixed land uses, human friendly streets and restrictive parking are vital to reduce car dependency in rapidly motorizing Chinese cities. On the basis of previous studies, this research will examine the topic of land use and travel behaviour from a new perspective to fill the gap and enrich the existing studies.

As mentioned, the aim of this study is to analyse the characteristics of spatial distribution of daily travel activities and find the relationship between the activity destination spatial distribution and land use characteristics, which will be conducive to the construction of an intensive transport environment to guide residents to use public transportation. First a new travel pattern classification is proposed. The spatial analysis is then used to analyse and compare the spatial distribution characteristics of different daily travel patterns. Based on the spatial distribution characteristics, this study will explain how land use types influence travel activities using econometric approaches. Xiaoshan District of Hangzhou City, China, is used as a case study. One of the main contributions of this paper is the introduction of a new classification of the daily travel patterns that include single-activity travel, multi-activity intermittent travel, and multi-activity continuous travel. This classification focuses on the travel behaviours of how travellers arrange their daily activities, rather than the specific activities they complete. It can more accurately describe different travel patterns from the perspective of activity. A study of their spatial distribution will reveal a certain extent of the relationship between different activity spaces, which can help improve land use and infrastructure planning to reduce unnecessary travels.

The study is organized as follows. First, a brief review of related studies is provided, followed by the methodology. The study region and data are then described, followed by the results and discussions. In conclusion, the value of study results is discussed, along with the possible scope for the future research.

\section{RELATED STUDIES}

Jones et al. [10] defined the activity-based travel analysis as a framework in which travel is a daily or multi-day pattern of behaviour, "related to and derived from differences in life styles and activity participation among the population." Studies of travel activity mainly focused on daily travel behaviour. To explore the characteristics of multiple activity behaviours, Stopper et al. [11] and Krizek [12] classified activities into three primary groupings according to whether the primary travel characteristics were fixed: mandatory activities (such as commuting and schooling), maintenance activities (such as shopping and banking), and optional activities (such as social activities and tourism). According to trip purposes and activity sequences, Hedau and Sanghai [13] classified the commuting-generated trip into five activity patterns and Molla et al. [14] classified the randomly selected trip data into nineteen activity patterns. They all found that the majority of activity patterns are simple activity patterns such as Home-Work-Home (HWH), HomeOther-Home $(\mathrm{HOH})$. Furthermore, depending on the number of places visited within the tour, Ye et al. [15] classified the tour into two categories: simple tour with a single stop or activity outside the home location and complex tour with more than one stop outside the home location. No matter how the activities are classified, it was found that a person's travel activity patterns were stable in activity purposes and destination spaces [16]. However, there are many different types of activities, and their 
spatial distributions are quite different. Limited studies focus on the spatial distribution patterns of the out-of-home activities, and their relationship with functional structure of the city. This is particularly so in the Chinese context where a vast majority of literature focuses on travel behaviour instead of activity behaviour [7], let alone the distributions of activities. This research aims to fill this gap.

The potential influence of functional structure of the city on the travel activity behaviour has been widely researched. Early studies of land use and travel behaviours show that land use characteristics, such as land use intensity and mixed use, are found to have a significant impact on travel decisions [1720]. Pitombo et al. [21] and João et al. [22] found that areas with high degree of mixed land use increase the number of trips using sustainable travel modes like public transportation and non-motorized modes, and travellers there prefer to accomplish short travel distances. Especially, a high degree of mixed land use around a workplace might be associated with a more complex trip chain pattern including both vehicle and walking trips, and residents may have more non-work activities before and after their work time [20, 22, 23]. As a result, the land use at destinations has been pointed out as a better way to predict trip chains and explain some behaviours than at origins [24-26]. Resident activities appear to agglomerate towards city central areas in both travel volume and direction due to the area multifunctional land use [27]. Thus, land use planning should consider a community centre with mixed functions, providing concentrated commerce and public facilities which can redesign the traffic flow, to satisfy the diverse travel demand of residents and simultaneously improve public transportation service $[28,29]$. A mixed function building is an urban entity integrating a variety of urban functions such as offices, markets, hotels, catering, entertainment, apartments, parks and public transportation into one [30]. Furthermore, a mixed function building can attract more people to do various activities, which indicate that travel activities can be clustered actively in spaces.

The data of Points of Interest (POI) play an important role for activity-based urban land use, and have been widely used in studying this topic [31]. POI is a specific point location that someone may find useful or interesting, such as catering sites, shopping, entertainment facilities, administrative institutions, schools, parking lots, hospitals, banks, companies, governmental institutions and residential sites [32]. Scholars studied the functional structure of the city by mainly using POI data and proposing frameworks to identify the functional regions of a city. For instance, Long and Shen [33] and $\mathrm{Yu}$ et al. [34] established a method to discover zones with different functions by combining POI data with smart card data and floating car track data, respectively. Yuan et al. [35] proposed a framework for discovering functional zones in a city through the analysis of human mobility trajectories among regions and POIs within regions. Then Chen et al. [36] made a comparative analysis with 25 Chinese city urban functional structures, and found that their manifestations of POI mixture patterns vary greatly from one city to another, although the city structures are relatively similar. However, these studies place less emphasis on the correlations between functional structure of the city and travel activity behaviours from the aspect of POI. The distribution pattern and density of POIs influence the travel activity behaviours by significantly affecting the urban land use planning [37]. For example, Yao and Wang [38] note that in China, danwei or type of work unit is an important institutional factor in explaining jobs - housing relationship and commuting behaviour. In particular, hukou, or household registration, is a crucial institutional factor that influences the individuals' mobility and travel behaviour.

\section{RESEARCH METHODS}

\subsection{Travel pattern classification}

The daily travel pattern of each person is classified in two steps. First, it is classified into single-activity travel and multi-activity travel according to the total number of activities the travellers carry out. Then, multi-activity travel is classified into multi-activity intermittent travel and multi-activity continuous travel based on the times of returning home during full-day schedules. Finally, the travel pattern is divided into three categories (as shown in Figure 1) as follows:

a) single-activity travel: travellers carry out one daily activity with one stop at the destination;

b) multi-activity intermittent travel: travellers go to multiple destinations to carry out at least two daily activities and return back home several times during the full day multi-activity schedules; 


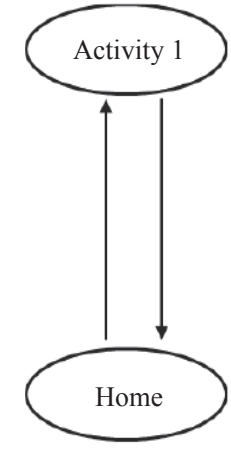

a) Single-activity travel

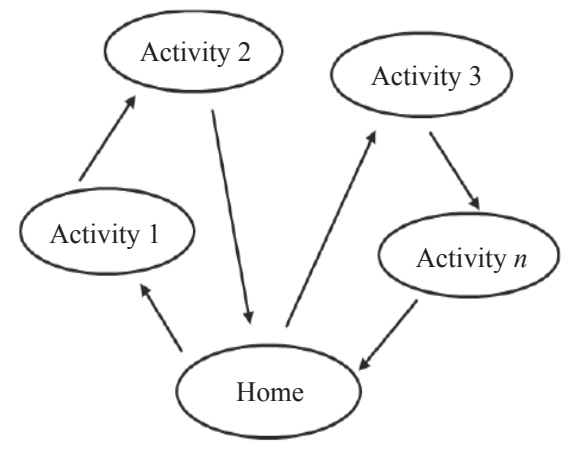

b) Multi-activity intermittent travel

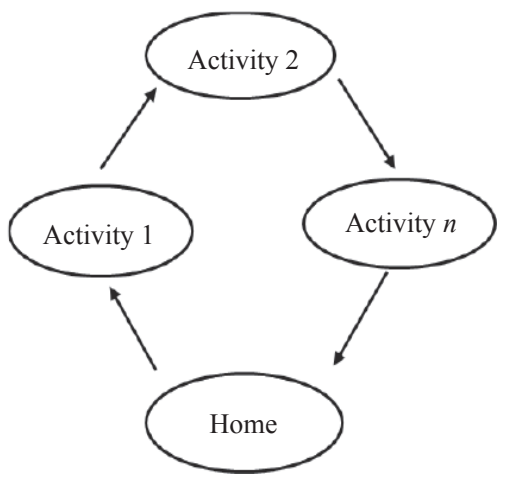

c) Multi-activity continuous travel

Figure 1 - Classification of daily activities

c) multi-activity continuous travel: travellers go to multiple destinations to carry out at least two daily activities and do not come back home until the end of the travel during the full day multi-activity schedules.

\subsection{Spatial analysis}

ArcGIS spatial analysis is a quantitative study method for geospatial phenomena. In this study, the spatial characteristics of different activities, and the matching degree of non-home activity destinations and POIs, as well as the spatial location relationship between them are explored and described by utilizing the analysis techniques. Kernel density estimation is used as the main analytical tool. Walking distance is a critical factor for travellers in the choice of service facilities. Following Wang and Du [39], the thresholds of limit and suitable walking distance are set as $950 \mathrm{~m}$ and $787 \mathrm{~m}$, respectively. The analysis scale is defined as a 600 -metre radius considering that the actual walking path may have a detour [40].

The kernel density estimation is a non-parametric way of estimating the probability density function of a random variable. It infers about the population based on a finite data sample. In the process of analysing the travel activities, the activity points are fitted into a smooth tapered surface, and the activity density of the point elements around each output grid pixel is calculated using the kernel density function. The density of each output grid pixel is the sum of all the values superimposed on the centre of the grid pixel. If the area unit is selected, the calculated pixel density is multiplied by the corresponding factor and then written on the output grid. The results are classified by Jenks natural breaks classification method instead of equal spacing. This method is a data clustering method designed to determine the best arrangement of values into different classes. Its calculation is an iterative process, and the objective is to seek a set of breaks with minimum in-class deviation and maximum variance between classes [41].

Given that the number of POIs and activity destinations is out of proportion, the normalization is needed to make further comparison. After their kernel density estimation, the grid reclassification is carried out, and the values of classes are reassigned. On the basis of reclassification, the difference between the activity destination density and POI density can be compared by calculating the relative density of POI using subtraction. The threshold value is set to 1 by cluster analysis. For the two grids at the same position, if the difference is within 1 , it can be considered that they have no difference; if the difference is greater than 1 , they are significantly different.

\subsection{Econometric approaches}

Estimating the matching degree of activity destination distribution and POI distribution can help understand the relationship between the density of POI and the number of activity destinations. It is specified that one POI is the same as one activity destination, and the impact of POI distribution on the travel activity patterns can be directly reflected. It is quantified to find the reasonable POI combinations for attracting more activities, especially multi-activity continuous travels.

Thus, the multiple linear regression analysis is considered for this study and presented as follows: 


$$
Z=\beta_{0}+\beta x+\alpha y+u
$$

where $Z$ is the number of the non-home activity destinations of multi-activity continuous travels; $x$ is a vector of different types of POIs including shops, banks, catering facilities, parking spaces, and entertainment facilities; $y$ is a vector of social-demographic variables including gender, income, education, travel purposes, car ownership, household registration, etc.; $u$ is the error term.

\section{DATA DESCRIPTION}

\subsection{Study region}

Xiaoshan District in Hangzhou City, Zhejiang

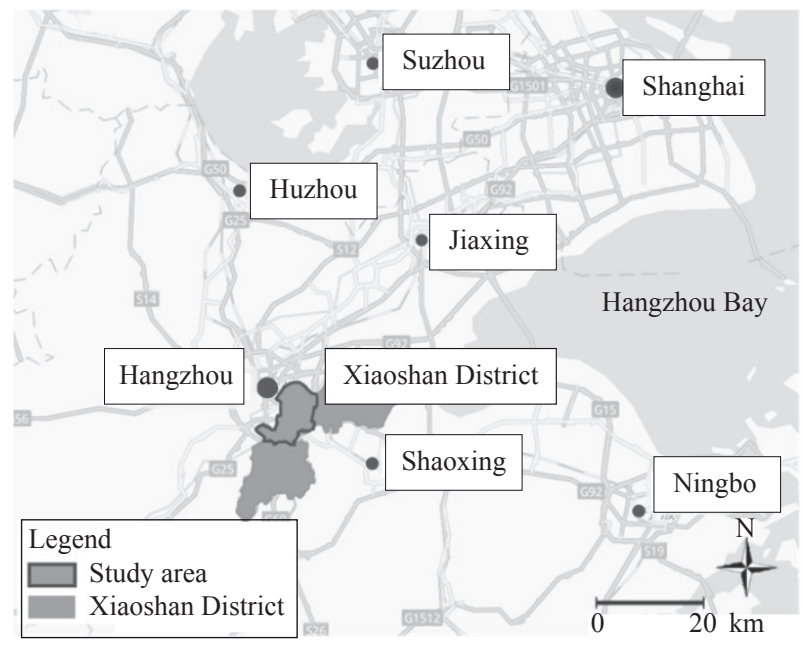

Figure 2 - The study region of the Xiaoshan District in Hangzhou

Province, China, is chosen as a case study (the grey area in Figure 2). The study region is limited to the urban area of Xiaoshan District (the grey area within the border in Figure 2). Xiaoshan District is located in the southern wing of the Yangtze River Delta, at the southwest of Shanghai, with a household population of 1.246 million in 2015 , out of which 788,000 reside in urban areas and 476,000 reside in rural areas. The annual per capita disposable income of urban and rural residents is $\$ 7,631$ and $\$ 4,062$, respectively [42].

\subsection{Data}

The travel data used in this research are from the Xiaoshan Resident Travel Survey conducted in May 2015. The survey was carried out by investigators of the local government, and 5,505 questionnaires were received. These initial questionnaires consisted of three sections. The first part consists of individual travel information, including total travel time, origin and destination with corresponding latitude and longitude, trip purpose, travel mode, and so on. The second part collects individual demographic information, including gender, age, occupation, education level. The third part includes household information, such as household registration, annual income and car ownership. The demographic information is summarized in Table 1.

The geographical information data include administrative boundary and POI data of Xiaoshan District that are collected from Baidu Map. The POI data contain the coordinate information of catering, shopping, entertainment, administrative institutions, schools, parking lots, banks, companies, etc. in Xiaoshan.

\subsection{Data processing}

The original questionnaires were processed, and the following three cases were considered invalid and eliminated: (1) Incomplete questionnaires; (2) The activity destination is not in the scope of the study area; (3) The trip chain is obviously too complex (like the chain with more than six activities) and only appears once in the samples. After that, 5,384 valid questionnaires were obtained. The coordinates (latitude and longitude) for residences and non-home activity destinations, the total travel time, the total travel distance, the length and the types of activity chain, were extracted from the samples. According to the travel pattern classification, the sample sizes of single-activity travel, multi-activity intermittent travel, multi-activity continuous travel are $2,673,1,319,1,392$, respectively. All these travel activities contain 9,036 non-home activity destinations, out of which 2,673 belong to single-activity travel, 2,754 multi-activity intermittent travel, and 3,488 multi-activity continuous travel. Figure 3 shows the framework of data cleaning and processing.

For further analysis, the study region is divided into 18 Traffic Analysis Zones (TAZs), numbered in Figure $4 a$. Then, the number of different travel patterns in each TAZ is counted to explore the activity distribution, as shown in Figure $4 b$. The main activity space in Xiaoshan District concentrates in TAZ (8) and TAZ (10 (the red box area in Figure 4b), and TAZ (2) (grey area) is not included during the analysis because the sample size is too small. 
Li L, Cao M, Yin J, Wang Y, Zhang Y. Spatial Distribution of Travel Activities and its Relationship with Points of Interest

Table 1 -Individual and household attributes of different activity types

\begin{tabular}{|c|c|c|c|c|c|c|}
\hline & & \multirow{2}{*}{$\begin{array}{c}\text { Total travel } \\
\text { diaries }\end{array}$} & \multicolumn{2}{|c|}{ Single-activity trip chaining } & \multicolumn{2}{|c|}{ Multi-activity trip chaining } \\
\hline & & & Number & Proportion & Number & Proportion \\
\hline \multicolumn{2}{|c|}{ Samples } & 5,384 & 2,673 & $49.65 \%$ & 2,711 & $50.35 \%$ \\
\hline \multicolumn{7}{|c|}{ Gender } \\
\hline \multirow{26}{*}{ 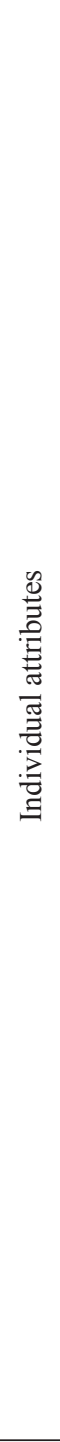 } & Male & 2,781 & 1,376 & $51.50 \%$ & 1,405 & $51.80 \%$ \\
\hline & Female & 2,603 & 1,297 & $48.50 \%$ & 1,306 & $48.20 \%$ \\
\hline & \multicolumn{6}{|c|}{ Age } \\
\hline & Under 25 & 570 & 327 & $12.20 \%$ & 243 & $9.00 \%$ \\
\hline & $26-40$ & 3,029 & 1,514 & $56.60 \%$ & 1,515 & $55.90 \%$ \\
\hline & $41-60$ & 1,728 & 809 & $30.30 \%$ & 919 & $33.90 \%$ \\
\hline & Above 60 & 57 & 23 & $0.90 \%$ & 34 & $1.30 \%$ \\
\hline & \multicolumn{6}{|c|}{ Occupation } \\
\hline & Factory-hand & 481 & 224 & $8.40 \%$ & 257 & $9.50 \%$ \\
\hline & Company employee & 2,839 & 1,400 & $52.40 \%$ & 1,439 & $53.10 \%$ \\
\hline & Head of private enterprise & 155 & 78 & $2.90 \%$ & 77 & $2.80 \%$ \\
\hline & Commercial service personnel & 219 & 99 & $3.70 \%$ & 120 & $4.40 \%$ \\
\hline & Students & 195 & 149 & $5.60 \%$ & 46 & $1.70 \%$ \\
\hline & Self-employed & 685 & 332 & $12.40 \%$ & 353 & $13.00 \%$ \\
\hline & Public official & 219 & 114 & $4.30 \%$ & 105 & $3.90 \%$ \\
\hline & Retired & 306 & 131 & $4.90 \%$ & 175 & $6.50 \%$ \\
\hline & Unemployed & 152 & 77 & $2.90 \%$ & 75 & $2.80 \%$ \\
\hline & Other & 133 & 69 & $2.60 \%$ & 64 & $2.40 \%$ \\
\hline & \multicolumn{6}{|c|}{ Education } \\
\hline & Primary school and below & 462 & 201 & $7.50 \%$ & 261 & $9.60 \%$ \\
\hline & Secondary school & 2,017 & 1,029 & $38.50 \%$ & 988 & $36.40 \%$ \\
\hline & Tertiary diploma & 2,087 & 1,076 & $40.30 \%$ & 1,011 & $37.30 \%$ \\
\hline & Tertiary degree & 818 & 367 & $13.70 \%$ & 451 & $16.60 \%$ \\
\hline & \multicolumn{6}{|c|}{ Driving license } \\
\hline & Yes & 3,466 & 1,640 & $61.40 \%$ & 1,826 & $67.40 \%$ \\
\hline & No & 1,918 & 1,033 & $38.60 \%$ & 885 & $32.60 \%$ \\
\hline \multirow{12}{*}{ 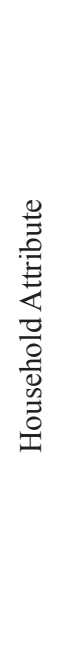 } & \multicolumn{6}{|c|}{ Household registration } \\
\hline & Local & 4,959 & 2,484 & $92.90 \%$ & 2,475 & $91.30 \%$ \\
\hline & Non-local & 425 & 189 & $7.10 \%$ & 236 & $8.70 \%$ \\
\hline & \multicolumn{6}{|c|}{ Household car ownership } \\
\hline & 0 & 836 & 411 & $15.40 \%$ & 425 & $15.70 \%$ \\
\hline & 1 & 3,064 & 1,517 & $56.80 \%$ & 1,547 & $57.10 \%$ \\
\hline & More than 1 & 1,484 & 745 & $27.90 \%$ & 739 & $27.30 \%$ \\
\hline & \multicolumn{6}{|c|}{ Household income (yuan) } \\
\hline & Below 100,000 & 1,601 & 869 & $32.50 \%$ & 732 & $27.00 \%$ \\
\hline & $100,000-300,000$ & 3,146 & 1,468 & $54.90 \%$ & 1,678 & $61.90 \%$ \\
\hline & $300,000-500,000$ & 553 & 300 & $11.20 \%$ & 253 & $9.30 \%$ \\
\hline & More than 500,000 & 84 & 36 & $1.30 \%$ & 48 & $1.80 \%$ \\
\hline
\end{tabular}




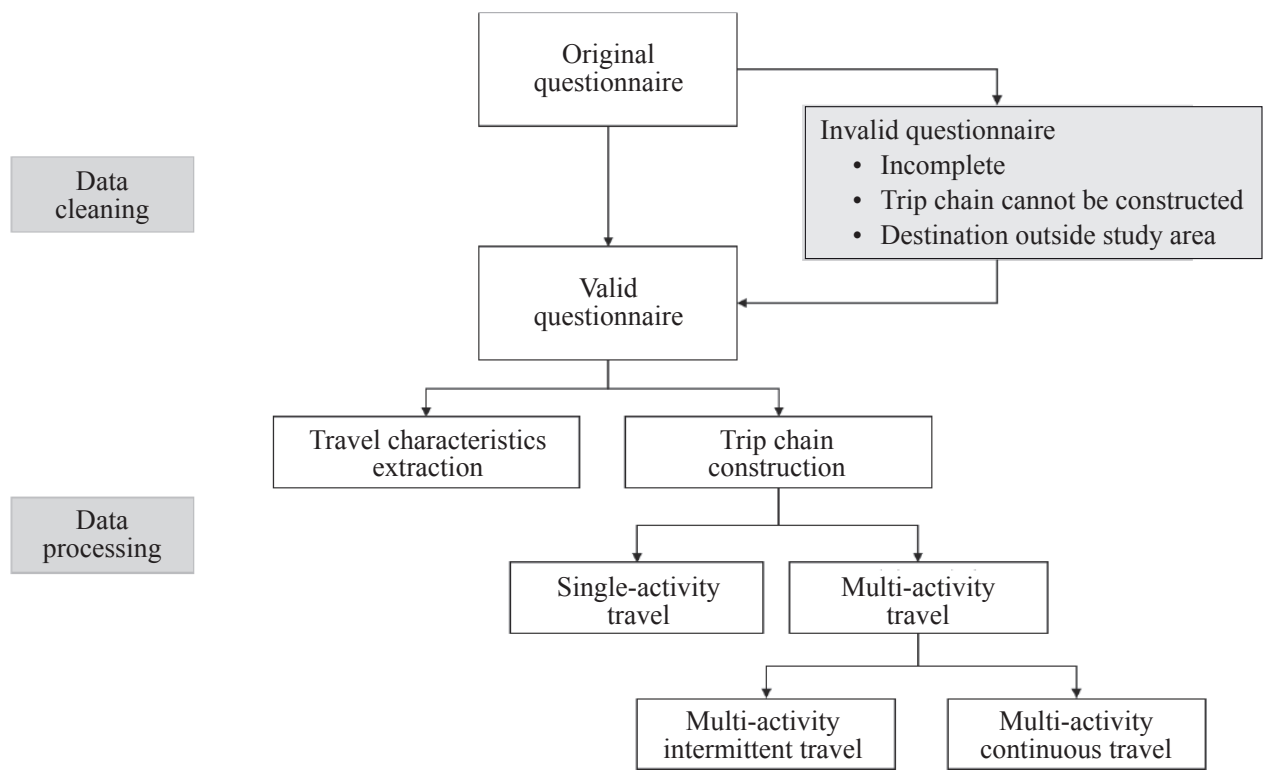

Figure 3 - Framework of data processing

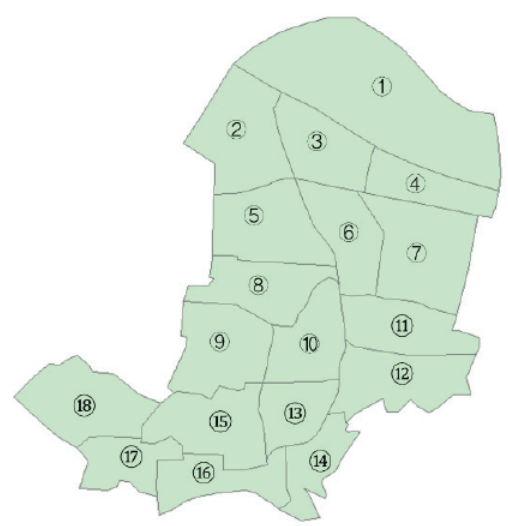

a) Traffic analysis zones

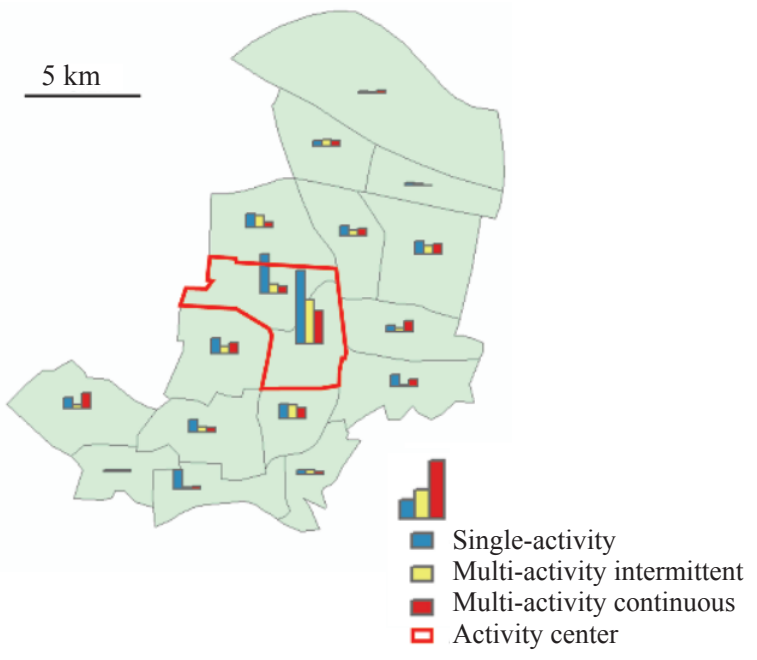

b) Activity chain distribution

Figure 4 - Traffic analysis zone division and activity chain distribution

\section{RESULTS AND DISCUSSION}

\subsection{Spatial distribution of activity characteristics based on residential places}

The spatial distribution of travel generated from all study regions, shown in Figure 5, mainly focuses on the red zone - activity centre. Considering all travel patterns, Figures $5 a-5 c$ show, for the majority of TAZs except TAZs (1) and (16) (the top and bottom TAZs in Figure 4a): (a) the total travel time in the activity centre is shorter than most other TAZs except for TAZ (1); (b) as the distance from the activity centre increases, the total travel distance becomes longer; and (c) the number of daily activities increases when the residence is far away from the activity centre. TAZs (1) and (16) are special because the proportion of internal travel is high and more private cars are used. The findings indicate that the residents' travel activities are centripetal, because the activity centre can provide diversified and better services to meet the residents' various activity demands. Figure $5 d$ also displays similar results. Residents who are close to the activity centre tend to prefer single-activity travel and multi-activity intermittent travel patterns over the multi-activity 


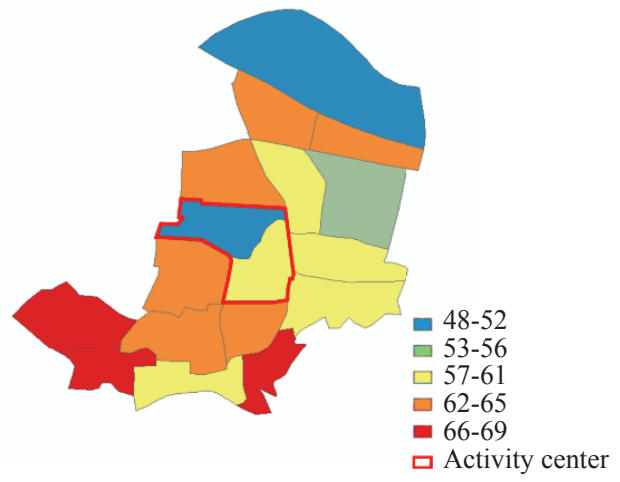

a) Total travel time [min]

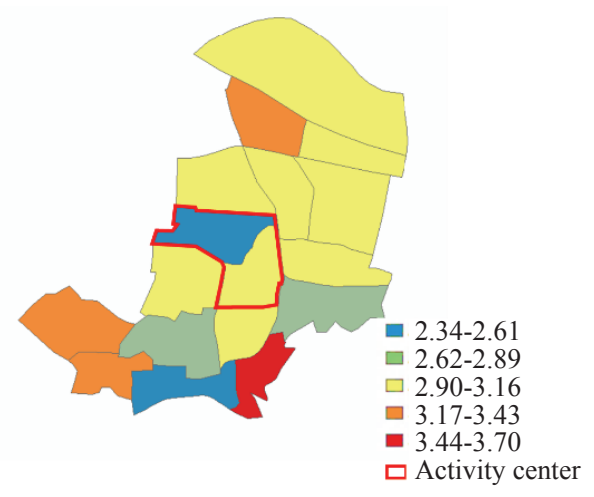

c) Number of daily activities

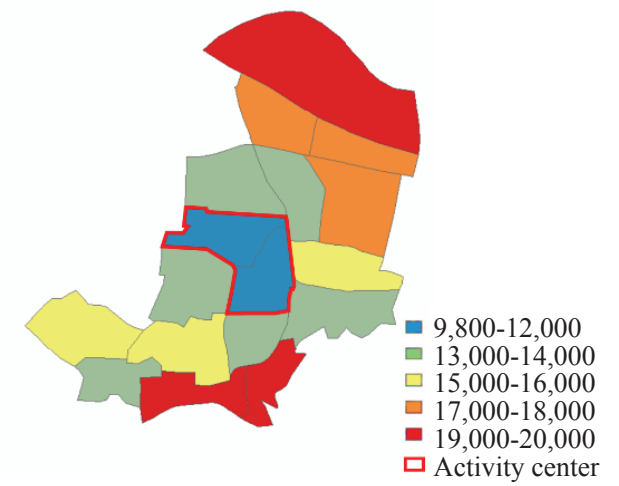

b) Total travel distance $[\mathrm{m}]$

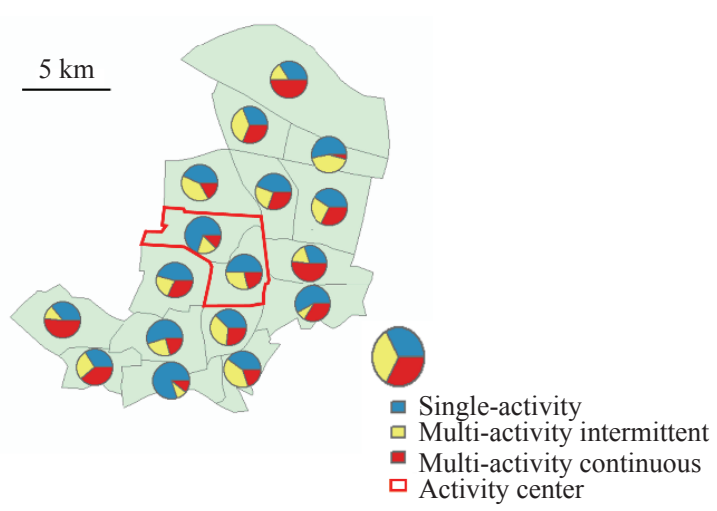

d) Proportion of different travel patterns

Figure 5 - Activity characteristics of each traffic zone

continuous travel pattern. In the peripheral area, the proportion of the multi-activity intermittent travel pattern decreases significantly, while the proportion of the multi-activity continuous travel pattern increases significantly.

\subsection{Spatial agglomeration of non-home activity destination based on travel pattern}

Figure 6 describes the spatial distribution of nonhome activity destinations in plane and 3D front view. The figures show that the spatial range of destination agglomeration is shrinking to the central area, with the highest density being distributed in a 600 -meter radius around the centre; and the degree of agglomeration increases in the order of single-activity travel, multi-activity intermittent travel, and multi-activity continuous travel.

Furthermore, it is easy to see from Figure 6 that the spatial distribution of destinations of different travel chains is obviously agglomerated in three regions. Then, these three regions are identified as typical regions for the next analysis, as shown in Figure 7. The regions are all in TAZ (8) and TAZ (10, the activity centre. The agglomeration degree of different travel patterns in these three regions is given in Table 2.

Table 2 shows that the proportion of multi-activity travel is relatively higher in Regions 2 and 3 than in Region 1. And more continuous travels occur in Region 3, the intermittent travel number is the largest in Region 2. The land use of the three regions is further investigated. Region 1 and its surrounding areas in a $600 \mathrm{~m}$ radius range have three mixed function buildings, shown as red stars in Figure 7; Region 2 has mixed land use and a large number of residential areas inside and around; Region 3 is a comprehensive building group with more public facilities such as supermarkets, restaurants, and entertainment industries. The land use characteristic reflects that areas with mixed land use can attract more activities, and will be more suitable for multi-activity travel especially continuous travel. 

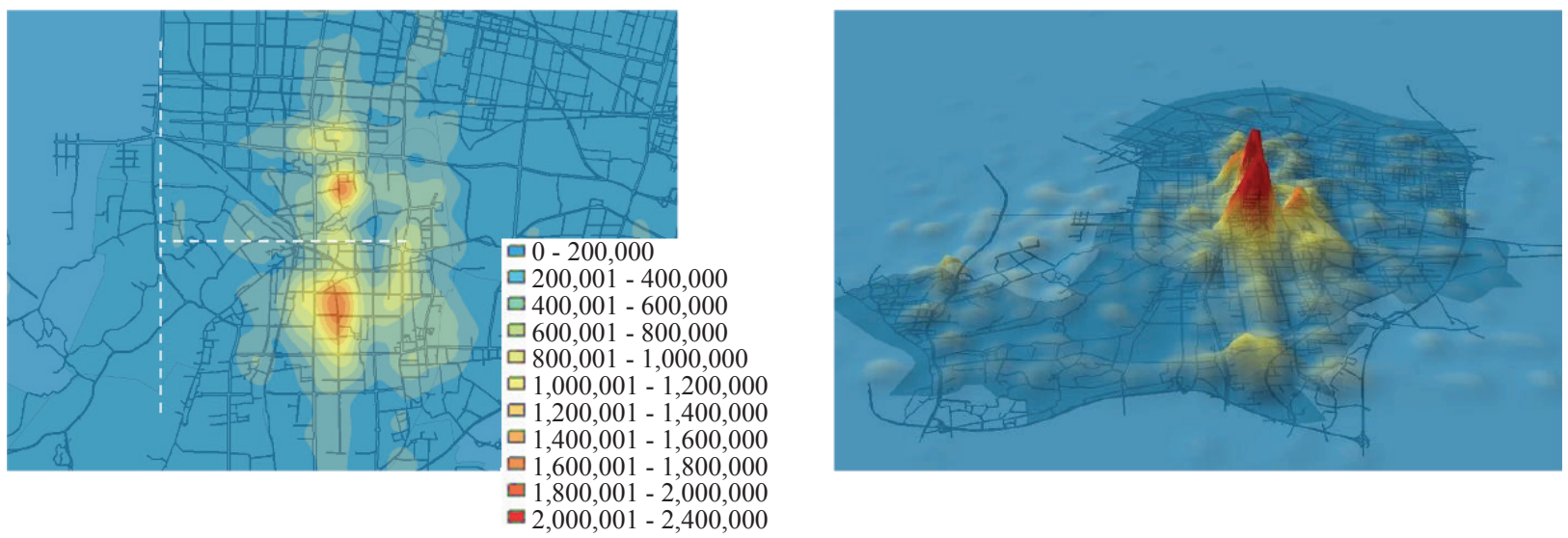

a) Spatial distribution of non-home activity destination of single-activity travel
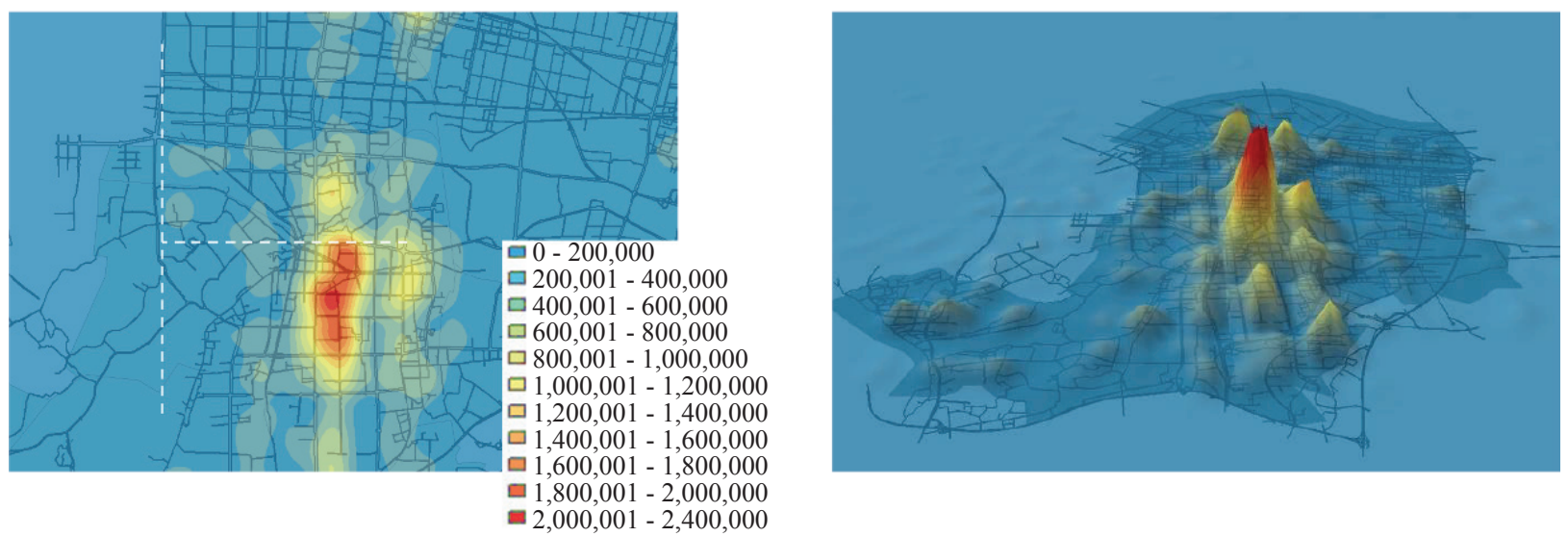

b) Spatial distribution of non-home activity destination of multi-activity intermittent travel
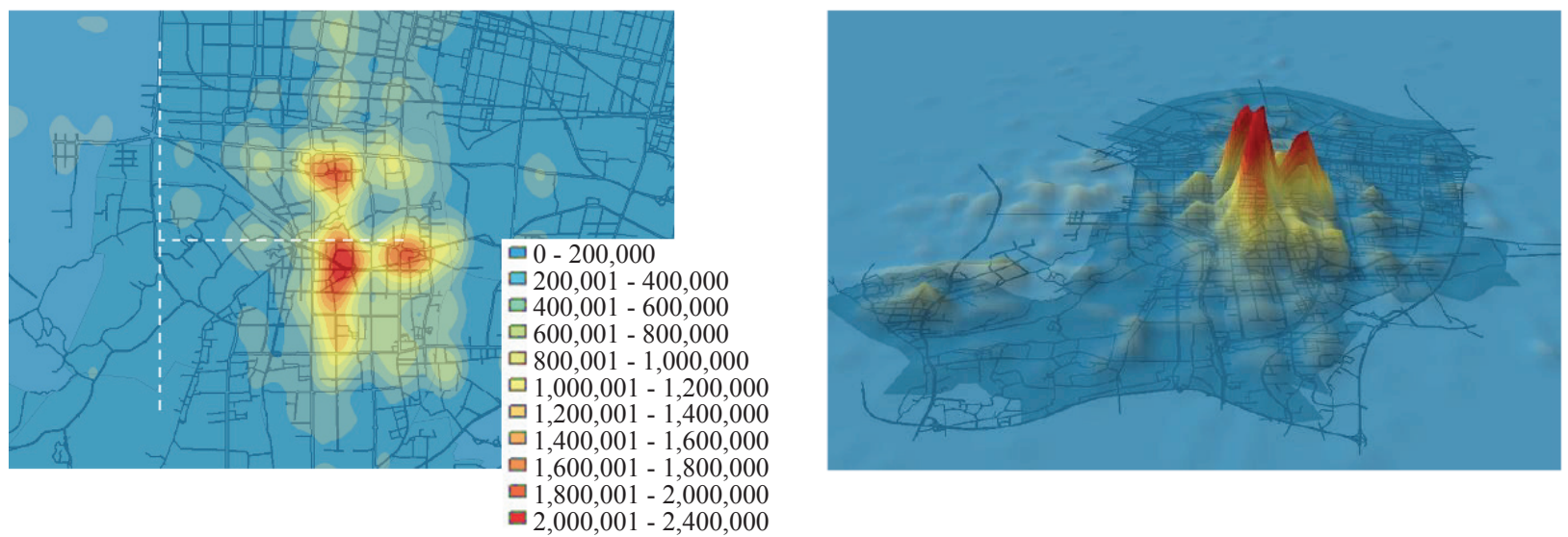

c) Spatial distribution of non-home activity destination of multi-activity continuous travel

Figure 6-Spatial distribution of non-home activity destination of different travel activity chains in plane and 3D front view

Table 2 - Average of kernel density estimation in three regions

\begin{tabular}{||c|c|c|c|c||}
\hline $\begin{array}{c}\text { Region } \\
\text { number }\end{array}$ & Single-activity travel & $\begin{array}{c}\text { Multi-activity intermittent } \\
\text { travel }\end{array}$ & $\begin{array}{c}\text { Multi-activity continuous } \\
\text { travel }\end{array}$ & $\begin{array}{c}\text { Proportion of three kinds of } \\
\text { activities }\end{array}$ \\
\hline \hline 1 & $1,305,281$ & 985,540 & $1,280,197$ & $36 \%: 28 \%: 36 \%$ \\
\hline 2 & $1,209,050$ & $1,627,407$ & $1,616,181$ & $27 \%: 37 \%: 36 \%$ \\
\hline 3 & 611,019 & 990,824 & $1,480,350$ & $20 \%: 32 \%: 48 \%$ \\
\hline
\end{tabular}




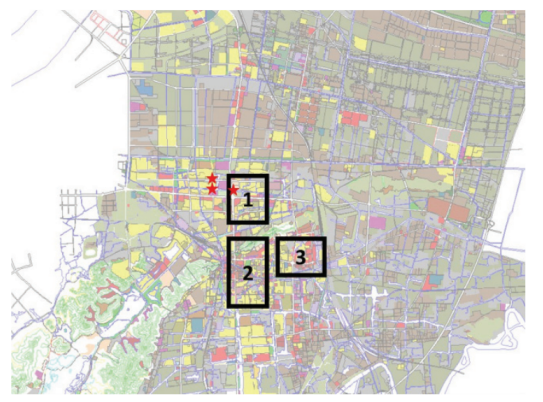

a) Typical regions

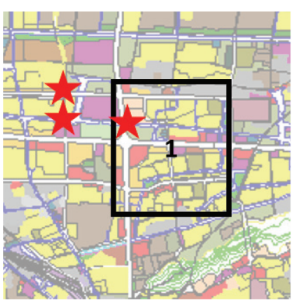

b) Region 1

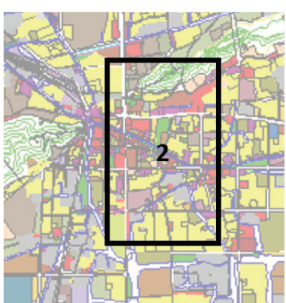

c) Region 2
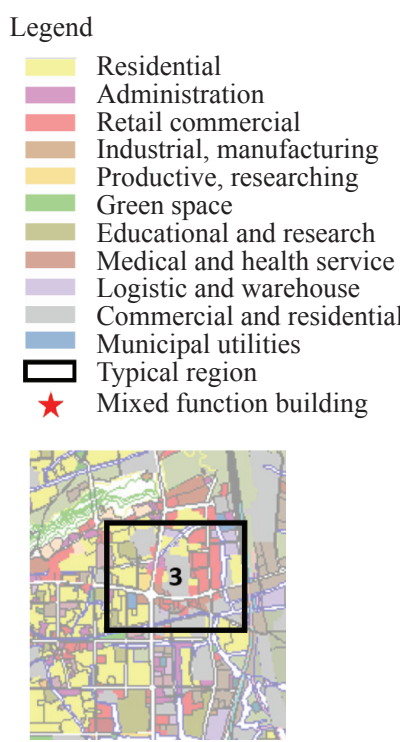

d) Region 3

Figure 7 - Analysis of typical regional characteristics

The travel activity chains related to the mixed function building are further divided into three types: travel that does not stop by a mixed function building, working at a mixed function building, and travel that stops by a mixed function building. Then the length and travel time of activity chains are compared in Table 3.
As can be seen in Table 3, the average length of daily activities of travel that stop by a mixed function building and working at a mixed function building are obviously longer than the total average length, indicating that the mixed function building attracts more multi-activity travels. Table 3 shows that multi-activity travels of working

Table 3 -Comparison of the influence of the mixed function building on travel activity chain

\begin{tabular}{|c|c|c|c|}
\hline \multicolumn{4}{|c|}{ Length of travel activity chain } \\
\hline Travel activity & Sample & $\begin{array}{c}\text { Average length of activity chain } \\
\text { (the number of travel activities completed } \\
\text { in a day) }\end{array}$ & $\begin{array}{l}\text { Average length of multi-activity } \\
\text { chain (except single-activity travel) }\end{array}$ \\
\hline Total & 5,384 & 2.88 & 3.75 \\
\hline $\begin{array}{l}\text { Travel that does not stop } \\
\text { by a mixed function } \\
\text { building }\end{array}$ & 5,119 & 2.87 & 3.68 \\
\hline $\begin{array}{l}\text { Working at a mixed } \\
\text { function building }\end{array}$ & 87 & 3.03 & 4.00 \\
\hline $\begin{array}{l}\text { Travel that stops by a } \\
\text { mixed function building }\end{array}$ & 178 & 3.43 & 3.85 \\
\hline \multicolumn{4}{|c|}{ Travel time of travel activity chain } \\
\hline \multicolumn{2}{|c|}{$\begin{array}{l}\text { Activity types related to mixed function } \\
\text { building }\end{array}$} & \multicolumn{2}{|c|}{ Travel time [min] } \\
\hline \multicolumn{2}{|c|}{$\begin{array}{l}\text { Single-activity } \\
\text { (working at a mixed function building) }\end{array}$} & \multicolumn{2}{|c|}{40.9 (length of activity chain is 2.00 ) } \\
\hline \multicolumn{2}{|c|}{$\begin{array}{l}\text { Multi-activity } \\
\text { (working at a mixed function building) }\end{array}$} & \multicolumn{2}{|c|}{73.6 (average length of activity chain is 4.00 ) } \\
\hline \multicolumn{2}{|c|}{$\begin{array}{l}\text { Single-activity } \\
\text { (travel that stops by a mixed function } \\
\text { building) }\end{array}$} & \multicolumn{2}{|c|}{43.0 (length of activity chain is 2.00 ) } \\
\hline \multicolumn{2}{|c|}{$\begin{array}{l}\text { Multi-activity } \\
\text { (travel that stops by a mixed function } \\
\text { building) }\end{array}$} & \multicolumn{2}{|c|}{80.3 (average length of activity chain is 3.85 ) } \\
\hline \multicolumn{2}{|c|}{ Total } & \multicolumn{2}{|l|}{45.5} \\
\hline
\end{tabular}




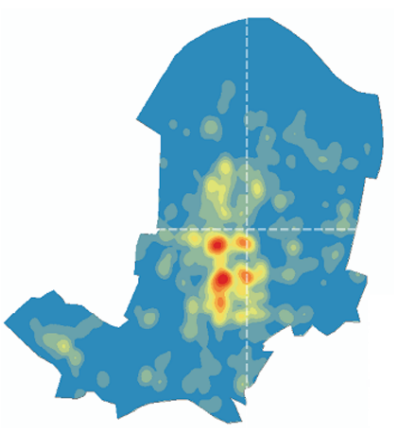

$0-144,000$

$\square 145,000-539,000$

$\square 540,000-1,110,000$

$\square 1,120,000-1,760,000$

$\square 1,770,000-2,480,000$

$\square 2,490,000-3,420,000$

$\square 3,430,000-4,460,000$

$\square 4,470,000-5,680,000$

a $5,690,000-7,190,000$

- 7,200,000 - 9,170,000

a) Distribution of activity destinations

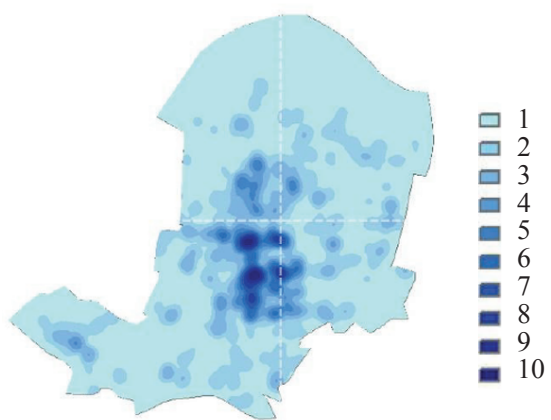

c) Reclassified distribution of activity destinations

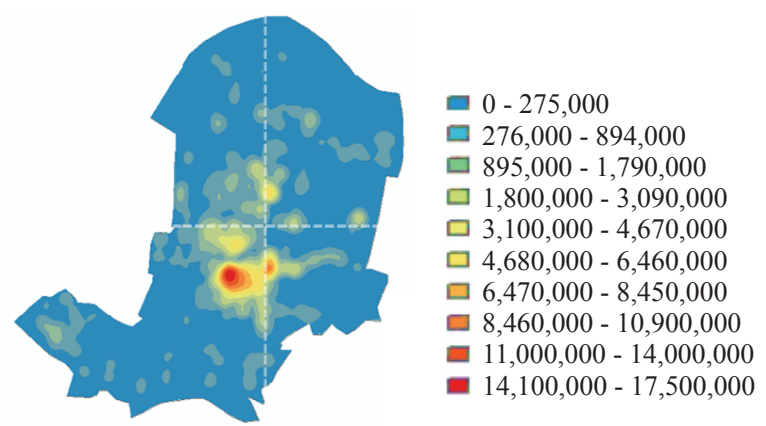

b) Distribution of POIs

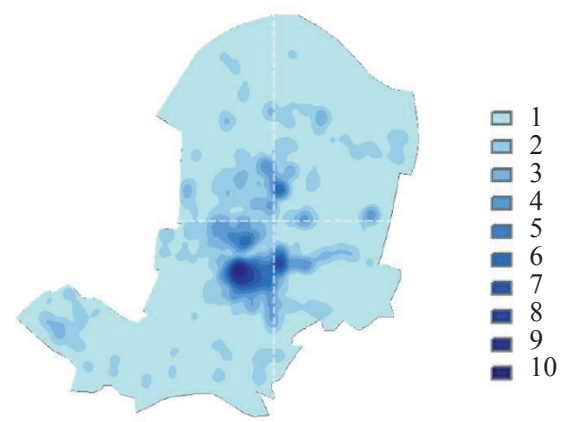

d) Reclassified distribution of POIs

Figure 8-Spatial distribution comparison of activity destinations and POIs

at a mixed function building have longer activity chain but shorter travel time than the travel that stops by a mixed function building. An interesting finding is that the travel time of multi-activity travel is not simply a single-activity travel time multiplied by the corresponding number of travels, but it is much shorter regardless of working at or travelling that stops by a mixed function building. Therefore, although a mixed function building provides limited jobs, it can integrate travel activities and promote residents to prefer multi-activity continuous travels, which is helpful to reduce the travel time and ease traffic congestion.

\subsection{Relationship between activity spatial distribution and POIs}

The density of activity destinations and POIs are compared with kernel density estimation, shown in Figures $8 a$ and $8 b$. Then they are normalized by grid reclassification to make further comparisons, and Figures $8 c$ and $8 d$ show the distribution of their density. It is easy to find that there is a high degree of coincidence between the two in spaces.
More specifically, using the density grade to calculate the relative density value of POI by subtraction, the matching degree between the activity destinations and POIs is tested, and the results are shown in Figure 9. The results reveal that the activity and POI density match approximately in $91.5 \%$ of the region (blue colour) and the relative density of POI is high in $2.0 \%$ of the region (red colour)

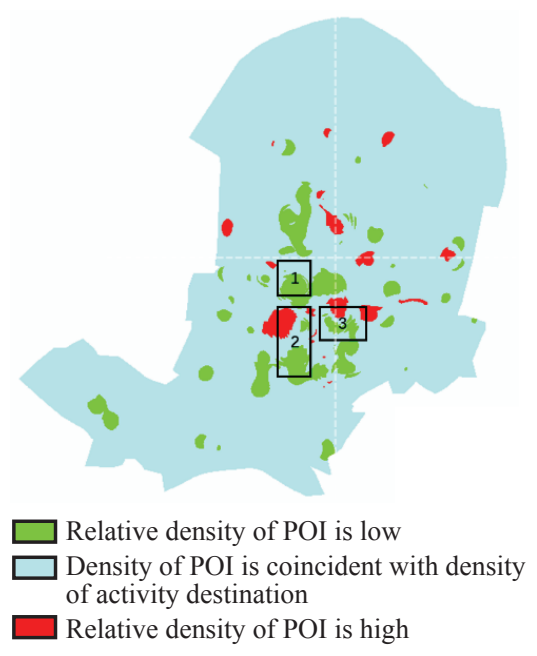

Figure 9 - Relative density distribution of POIs 
and low in $6.5 \%$ (green colour). Using the concept of beneficial result for further analysis, the beneficial result of POI equals the number of activities attracted to the number of POIs. The results shown in Figures 8 and 9 indicate that where the relative density is low, the beneficial result of POI is high, meaning a small number of POIs can attract more activities. Coupled with Figure 7, the three regions all contain areas with a low relative density of POI, especially in Region 1. The result suggests that a reasonable distribution of POIs like a mixed function building can attract more multi-activity travels, especially more multi-activity continuous travels, and greatly improve the beneficial result of POIs by integrating POIs in vertical and horizontal spaces. It can be concluded that the distribution of POIs has an influence on the agglomeration of travel activities, and effective combinations of different POIs have higher beneficial result, providing support for integrating land use to attract more activities to help reduce the use of private cars. Furthermore, the agglomeration effect of mixed function buildings presented in this paper is confirmed by analysing data from Shanghai and Dongguan [43].

\subsection{Relationship between the number of non-home destinations and demographics}

ArcGIS is used to partition Xiaoshan District into 1,073 grids with the area of each grid being 500 $\mathrm{m} * 500 \mathrm{~m}$. The numbers of various POIs in each grid and the respondents' demographic information are collected as independent variables. The number of non-home destinations of each multi-activity continuous travel in each grid is also collected as a dependent variable. The regression results including the descriptive statistics are reported in Table 4.

Table 4 suggests that the shopping facilities and job-related POIs are positively and significantly associated with the number of destinations for multi-activity continuous travels. An increase in the parking facilities can also result in an increase in the number of non-home destinations. Catering POIs do not have a significant impact in increasing the number of non-home destinations. This may imply that people are not restricted by geographical limitations when performing their catering activities. Interestingly, the entertainment POIs and banks have the effect of reducing the number of destinations visited, probably suggesting that when people visit these places, other activities are less important and do not constitute their main travel purposes.

The coefficients of the demographic variables suggest that residents that do not have local household registration tend to travel to fewer destinations. There is no significant difference between men and women in terms of the number of destinations visited in continuous travels. It appears that younger people, i.e. those under 25 , would travel more places than those between 25 and 40 . However, the difference between the younger group and those aged 40 and above is not statistically significant.

People with higher education levels tend to travel more destinations compared with those who only completed the primary school. The respondents from the income groups with an annual household income between 100,000 and 500,000 also tend to visit more destinations than those with a lower income. Interestingly, people in the highest income group do not necessarily travel more or fewer places than in the lowest income group. It is also found that owning a car does not have a significant relationship with the number of places visited, nor do travel purposes.

\section{CONCLUSION}

This study focuses on the relationship between travel activity and urban space by correlating resident's travel behaviour and the location of POIs. Considering the activity interconnections, the study proposed a new classification of travel patterns including single-activity travel, multi-activity intermittent travel and multi-activity continuous travel. Xiaoshan District is selected as a case study, and spatial analysis methods are employed to analyse the resident's travel activities. The results show that the degree of agglomeration of nonhome activity destinations of single-activity travel, multi-activity intermittent travel, and multi-activity continuous travel increases in proximity to the activity centre where the mixed land use can provide various opportunities. The fact that there is more multi-activity continuous travel when travel origin is farther away from the activity centre is proved. The findings are consistent with the previous study that the travellers prefer to achieve more travel purposes by lower travel costs [44], and also supports that the combinations of high density, mix and transit accessible locations more likely to produce efficient trip chains of which travellers do 
Li L, Cao M, Yin J, Wang Y, Zhang Y. Spatial Distribution of Travel Activities and its Relationship with Points of Interest

Table 4 - Descriptive statistics and regression results

\begin{tabular}{|c|c|c|c|}
\hline Independent variable & Description & $\begin{array}{c}\text { Mean } \\
\text { (std. dev.) }\end{array}$ & $\begin{array}{l}\text { Coefficient } \\
\text { (robust std. err.) }\end{array}$ \\
\hline Catering & Number of food and drink shops & $\begin{array}{c}7.2 \\
(10.04)\end{array}$ & $\begin{array}{c}0.11 \\
(0.09)\end{array}$ \\
\hline Shops & Number of shops & $\begin{array}{c}30.9 \\
(48.77) \\
\end{array}$ & $\begin{array}{c}0.21 * * * \\
(0.05)\end{array}$ \\
\hline Entertainment & Number of sport and entertainment facilities & $\begin{array}{c}2.6 \\
(3.59)\end{array}$ & $\begin{array}{c}-1.68 * * * \\
(0.34)\end{array}$ \\
\hline Parking & Number of car parks & $\begin{array}{c}3.1 \\
(4.6)\end{array}$ & $\begin{array}{c}4.25^{* * *} \\
(0.30)\end{array}$ \\
\hline Job & Number of companies and government units & $\begin{array}{c}8.8 \\
(10.56)\end{array}$ & $\begin{array}{c}0.36^{* * *} \\
(0.14)\end{array}$ \\
\hline Banks & Number of banks & $\begin{array}{c}4.2 \\
(6.55)\end{array}$ & $\begin{array}{c}-0.70 * * * \\
(0.18)\end{array}$ \\
\hline Household register & $\begin{array}{l}\text { Taking the value of } 0 \text { if the respondent has local household } \\
\text { registration and } 1 \text { otherwise. }\end{array}$ & $\begin{array}{c}0.07 \\
(0.26)\end{array}$ & $\begin{array}{l}-3.77 * \\
(1.98)\end{array}$ \\
\hline Gender & $\begin{array}{l}\text { Taking the value of } 0 \text { if the respondent is male and } 1 \text { if } \\
\text { female }\end{array}$ & $\begin{array}{c}0.46 \\
(0.50)\end{array}$ & $\begin{array}{l}-0.01 \\
(1.15)\end{array}$ \\
\hline \multirow{2}{*}{$\begin{array}{l}\text { Age groups (base } \\
\text { group: } 25 \text { or below) }\end{array}$} & $26-40$ years & $\begin{array}{c}0.59 \\
(0.49)\end{array}$ & $\begin{array}{l}-6.08 \\
(2.12)^{* * *}\end{array}$ \\
\hline & Over 40 & $\begin{array}{c}0.32 \\
(0.47) \\
\end{array}$ & $\begin{array}{l}-3.31 \\
(2.38)\end{array}$ \\
\hline \multirow{3}{*}{$\begin{array}{l}\text { Education } \\
\text { (base group: primary } \\
\text { or below) }\end{array}$} & Secondary school & $\begin{array}{c}0.33 \\
(0.47) \\
\end{array}$ & $\begin{array}{c}6.23 * * * \\
(2.03)\end{array}$ \\
\hline & Tertiary diploma & $\begin{array}{c}0.41 \\
(0.49) \\
\end{array}$ & $\begin{array}{l}5.42 * * \\
(2.27) \\
\end{array}$ \\
\hline & Tertiary degree & $\begin{array}{c}0.18 \\
(0.38) \\
\end{array}$ & $\begin{array}{l}4.54^{*} \\
(2.50) \\
\end{array}$ \\
\hline \multirow{3}{*}{$\begin{array}{l}\text { Household income } \\
\text { (base: } 100,000 \text { yuan } \\
\text { or below) }\end{array}$} & $100,000-300,000$ yuan & $\begin{array}{c}0.59 \\
(0.49) \\
\end{array}$ & $\begin{array}{c}4.50 * * * \\
(1.32)\end{array}$ \\
\hline & $300,000-500,000$ yuan & $\begin{array}{c}0.12 \\
(0.32) \\
\end{array}$ & $\begin{array}{c}8.07 * * * \\
(1.94) \\
\end{array}$ \\
\hline & Over 500,000 yuan & $\begin{array}{c}0.02 \\
(0.14)\end{array}$ & $\begin{array}{l}-1.44 \\
(4.63)\end{array}$ \\
\hline Car ownership & $\begin{array}{l}\text { Taking the value of } 1 \text { if the household owns a car and } 0 \\
\text { otherwise }\end{array}$ & $\begin{array}{c}0.30 \\
(0.49) \\
\end{array}$ & $\begin{array}{c}1.28 \\
(1.34) \\
\end{array}$ \\
\hline \multirow{3}{*}{$\begin{array}{l}\text { Travel purposes } \\
\text { (base: other) }\end{array}$} & Work-related & $\begin{array}{c}0.45 \\
(0.50) \\
\end{array}$ & $\begin{array}{c}0.56 \\
(3.32) \\
\end{array}$ \\
\hline & Shopping & $\begin{array}{c}0.40 \\
(0.49)\end{array}$ & $\begin{array}{c}3.34 \\
(3.36)\end{array}$ \\
\hline & Entertainment & $\begin{array}{c}0.12 \\
(0.32)\end{array}$ & $\begin{array}{c}4.76 \\
(3.65)\end{array}$ \\
\hline \multicolumn{3}{|l|}{$\mathrm{R}^{2}$} & 0.615 \\
\hline \multicolumn{3}{|l|}{$\mathrm{N}$} & 1264 \\
\hline
\end{tabular}

$* p<0.05, * * p<0.01, * * * p<0.001$

more activities at fewer destinations [25]. Thus, it can explain that efficiently integrating the destinations of daily activities into one zone, or chaining multiple activities together in one tour, may provide greater convenience than a series of single-stop simple tours [45]. Take the mixed function building for example, the results support that mixed function buildings can integrate the residents' travel activities and provide a more continuous travel environment.

The relationship between spatial distribution of travel activities and POIs is analysed to explore the influence of land use on activity chains behaviour. The agglomeration phenomena show that the 
distribution of activity density has correlation with POIs. POIs can attract more activities, and reasonable POI combinations can attract more multi-activity travels. The regression model suggests that parking facilities, and shopping and job related POIs have a significant relationship with multi-activity continuous travels, whereas catering POIs are not statistically associated with the number of places visited. Interestingly, entertainment POIs and banks have a negative impact on the continuous travels.

The results of this study provide reference for guiding residents' activities and constructing multi-activity agglomeration area with mixed land use. If the area can be coordinated with intensive public transportation, the use of cars may effectively decrease, while the use of public transportation will improve, which is conducive to the sustainable development of urban traffic. This study is limited to the perspective of one-day travel activities, and only analyse the activity destination characteristics and the influence of urban space on activity. Further research should be carried out on the long-period of travel activities to explore the correlation between urban space and the residents' activity space. For the POI layout, the diversity of jobs as well as stores should be considered in further research to analyse the influences of different POI combinations and a more reasonable ratio. However, the conclusions need to be confirmed or adjusted in other countries and regions because of cultural differences.

\section{ACKNOWLEDGEMENTS}

This work was supported by the National Natural Science Foundation of China (Grant number 71804127); the Shanghai Philosophy and Social Science Planning Project (Grant number 2017BGL029); the 2016 Tongji University Youth Excellent Talents Project (Grant number 2016KJ031); and the Fundamental Research Funds for the Central Universities - Tongji University (Grant number 22120170164). The authors would also like to thank Dr. Shi Cheng for providing the data.

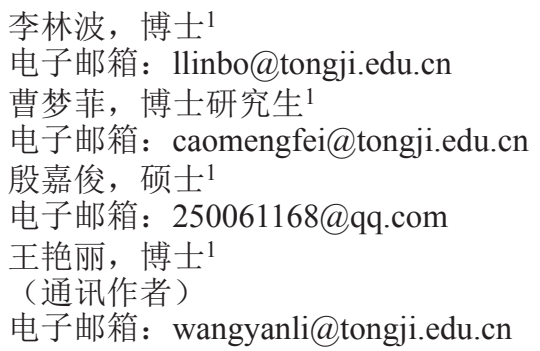

张亚华, 博士 ${ }^{2}$

电子邮箱: yahua.zhang@usq.edu.au

1 同济大学道路与交通工程教育部重点实验室 中国上海市嘉定区曹安公路 4800 号

2 南昆士兰大学商学院

澳大利亚昆士兰州图翁巴

出行活动的空间分布特征及其与兴趣点的关系

摘要

本研究利用中国杭州市萧山区2015年居民出行 调查数据, 探究了出行活动的空间分布特征及其与 土地利用的关系。研究提出了一种新的出行活动模 式分类方法, 将居民日常出行活动分为: 单活动出 行, 多活动间断出行和多活动连续出行。本文的主 要结果包括: (a) 活动链的长度和多活动出行的比 例随着居住地与城市活动中心之间距离的增加而增 加; (b) 单活动出行、多活动间断出行和多活动连续 出行的非家目的地点向活动中心集聚, 且在空间上 的集聚程度依次递增; (c) 兴趣点 $(P O I)$ 和活动目的 地点的分布密度在空间上呈强正相关; $(d)$ 兴趣点和 人口统计学的一些属性对多活动连续出行有显著影 响。研究结果有助于通过在城市规划中兴趣点的合 理组合与空间联系引导出行活动。

\section{关键词}

城市规划; 出行活动; 土地利用; 空间

分布; 多活动出行; 兴趣点布局

\section{REFERENCES}

[1] Farooq D, Moslem S, Duleba S. Evaluation of driver behaviour criteria for evolution of sustainable traffic safety. Sustainability. 2019;11(11): 3142. DOI: 10.3390/ su11113142

[2] Moslem S, Farooq D, Ghorbanzadeh O, Blaschke T. Application of the AHP-BWM model for evaluating driver behaviour factors related to road safety: A case study for Budapest. Symmetry. 2020;12(2): 243. DOI: 10.3390/ sym 12020243

[3] Ratner KA, Goetz AR. The reshaping of land use and urban form in Denver through transit-oriented development. Cities. 2013;30: 31-46. DOI: 10.1016/j.cities. 2012.08.007

[4] Pacione M. (ed.) The City: Land use, structure, and change in the Western city. London, UK: Routledge; 2002.

[5] Pacione M. Urban geography: A global perspective. $3^{\text {rd }}$ Ed. Abingdon, UK: Routledge; 2009.

[6] Pacione M. Urban environmental quality and human wellbeing - a social geographical perspective. Landscape and Urban Planning. 2003;65(1-2): 19-30. DOI: 10.1016/S0169-2046(02)00234-7

[7] Wang D, Zhou M. The built environment and travel behaviour in urban China: A literature review. Transportation Research Part D: Transport and Environment. 2017; 52: 574-585. DOI: $10.1016 / j . t r d .2016 .10 .031$

[8] Wang D, Cao X. Impacts of the built environment on activity-travel behaviour: Are there differences 
between public and private housing residents in Hong Kong? Transportation Research Part A: Policy and Practice. 2017;103: 25-35. DOI: 10.1016/ j.tra.2017.05.018

[9] Jiang Y, Gu P, Chen Y, He D, Mao Q. Influence of land use and street characteristics on car ownership and use: Evidence from Jinan, China. Transportation Research Part D: Transport and Environment. 2017;52: 518-534. DOI: $10.1016 /$ j.trd.2016.08.030

[10] Jones P, Koppelman F, Orfueil, JP. Activity analysis: state-of-the-art and future directions. In: Jones P. (ed.) Developments in Dynamic and Activity Based Approaches to Travel Analysis. Aldershot, UK: Gower Publishing; 1990. p. 34-55.

[11] Stopher PR, Hartgen DT, Li Y. SMART: Simulation model for activities, resources and travel. Transportation. 1996;23(3): 293-312. DOI: 10.1007/BF00165706

[12] Krizek KJ. Neighborhood services, trip purpose, and tour-based travel. Transportation. 2003;30(4): 387-410. DOI: $10.1023 / \mathrm{A}: 1024768007730$

[13] Hedau AL, Sanghai S. Development of trip generation model using activity based approach. International Journal of Civil, Structural, Environmental and Infrastructure Engineering Research and Development. 2014;4(3): 61-78. Available from: https:/www.researchgate.net/ publication/264122534

[14] Molla MM, Stone ML, Motuba D. Developing an activity-based trip generation model for small/medium size planning agencies. Transportation Planning and Technology. 2017;40(5): 540-555. DOI: 10.1080/03081060.2017.1314505

[15] Ye X, Pendyala RM, Gottardi G. An exploration of the relationship between mode choice and complexity of trip chaining patterns. Transportation Research Part B: Methodological. 2007;41(1): 96-113. DOI: 10.1016/ j.trb.2006.03.004

[16] Schlich R, Axhausen KW. Habitual travel behaviour: Evidence from a six-week travel diary. Transportation. 2003;30(1): 13-36. DOI: 10.1023/A:1021230507071

[17] Cervero R. Built environments and mode choice: Toward a normative framework. Transportation Research Part D: Transport and Environment. 2002;7(4): 265-284. DOI: 10.1016/S1361-9209(01)00024-4

[18] Zhou S, Yan X. The relationship between urban structure and traffic demand in Guangzhou. Acta Geographica Sinica. 2005;60(1): 131-142. Available from: http://en.cnki.com.cn/Article en/CJFDTotal-DLXB200501014.htm

[19] Zhao Y, Chai YW. Tour-based travel decision making and related factors of urban residents. Urban Studies. 2010;17(10): 96-101. Available from: http://en.cnki.com. $\mathrm{cn} /$ Article_en/CJFDTotal-CSFY201010022.htm

[20] Ma J, Mitchell G, Heppenstall A. Daily travel behaviour in Beijing, China: An analysis of workers' trip chains, and the role of socio-demographics and urban form. Habitat International. 2014;43: 263-273. DOI: 10.1016/ j.habitatint.2014.04.008

[21] Pitombo C, Sousa A, Filipe L. Classification and regression tree, principal components analysis and multiple linear regression to summarize data and understand travel behaviour. Transportation Letters: International Journal of Transportation Research. 2009;1(4): 295-308. DOI:
10.3328/TL.2009.01.04.295-308

[22] João de Abreu e Silva, Martinez L, Goulias K. Using a multi equation model to unravel the influence of land use patterns on travel behaviour of workers in Lisbon. Transportation Letters: International Journal of Transportation Research. 2012:4(4): 193-209. DOI: 10.3328/ TL.2012.04.04.193-209

[23] Chen YJ, Akar G. Using trip chaining and joint travel as mediating variables to explore the relationships among travel behaviour, socio-demographics, and urban form. Journal of Transport and Land Use. 2017;11(1): 573588. DOI: $10.5198 /$ jtlu.2017.882

[24] Millward H, Spinney J, Scott D. Active-transport walking behaviour: Destinations, durations, distances. Journal of Transport Geography. 2013;28: 101-110. DOI: 10.1016/j.jtrangeo.2012.11.012

[25] Harding C, Miller EJ, Axhausen K. Multiple purpose tours and efficient trip chaining: An analysis of the effects of land use and transit on travel behaviour in Switzerland. Proceedings of $94^{\text {th }}$ Annual Meeting of the Transportation Research Board, 11-15 January 2015, Washington, DC, USA. Available from: https://www.researchgate.net/publication/281455283

[26] Vale DS, Pereira M. Influence on pedestrian commuting behaviour of the built environment surrounding destinations: A structural equations modeling approach. International Journal of Sustainable Transportation. 2016;10(8): 730-741. DOI: 10.1080/15568318.2016.1144836

[27] Wang D, Zhang J. The analysis of consumer trip characteristics and spatial structure of commercial facilities in Shanghai. City Planning Review. 2001;25(10): 6-14. Available from: http://en.cnki.com.cn/Article_en/CJFDTotal-CSGH200110001.htm

[28] Dai D, Yao D, Duan J. Comparison and reconstruction-A study on typical development patterns of community centre. Urban Planning Forum. 2013;31(6): 112-118. Available from: http://en.cnki.com.cn/Article en/CJFDTotal-CXGH201306016.htm

[29] Duleba S, Moslem S. Examining Pareto optimality in analytic hierarchy process on real Data: An application in public transport service development. Expert Systems with Applications. 2019;116: 21-30. DOI: 10.1016/ j.eswa.2018.08.049

[30] Dong H, Lu J. A study on the city synthesis acting as organizing form of compact cities. Urban Planning Forum. 2009;(1): 54-61. Available from: http://en.cnki.com.cn/ Article_en/CJFDTotal-CXGH200901012.htm

[31] Gao S, Janowicz K, Couclelis H. Extracting urban functional regions from points of interest and human activities on location-based social networks. Transactions in GIS. 2017;21(3): 446-467. DOI: 10.1111/tgis.12289

[32] Gan Z, Feng T, Wu Y, Yang M, Timmermans H. Station-based average travel distance and its relationship with urban form and land use: An analysis of smart card data in Nanjing City, China. Transport Policy. 2019;79: 137-154. DOI: 10.1016/j.tranpol.2019.05.003

[33] Long Y, Shen Z. Discovering functional zones using bus smart card data and points of interest in Beijing. In: Long Y, Shen Z. (ed.) Geospatial Analysis to Support Urban Planning in Beijing. Cham, Switzerland: Springer Publishing; 2015. p. 193-217. 
[34] Yu B, Wang Z, Mu H, Sun L, Hu F. Identification of urban functional regions based on floating car track data and POI data. Sustainability. 2019;11(23): 6541. DOI: $10.3390 / \mathrm{su} 11236541$

[35] Yuan N J, Zheng Y, Xie X. Discovering Functional Zones in a City Using Human Movements and Points of Interest. In: Thill JC. (ed.) Spatial Analysis and Location Modeling in Urban and Regional Systems. Berlin, Heidelberg: Springer Publishing; 2018. p. 33-62.

[36] Chen Y, Chen X, Liu Z, Li X. Understanding the spatial organization of urban functions based on co-location patterns mining: A comparative analysis for 25 Chinese cities. Cities. 2020;97: 102563. DOI: 10.1016/j.cities. 2019.102563

[37] Zhao X, Du H, Zhao P. 2013. Research on building database of urban POI based on normalization rules_ taking Jinan as a case study. Urban Geotechnical Investigation \& Surveying. 2013;4: 21-24. Available from: http://en.cnki.com.cn/Article_en/CJFDTotal-CSKC201304009.htm

[38] Yao M, Wang D. Mobility and travel behaviour in urban China: The role of institutional factors. Transport Policy. 2018;69: 122-131. DOI: 10.1016/j.tranpol.2018.05.012

[39] Wang N, Du Y. Resident walking distance threshold of community. Transport Research. 2015;1(2): 20-24. Available from: http://www.cnki.com.cn/Article/CJFDTotal-JTBH201502004.htm
[40] Pan H, Yang T, Wu J, Lu Y, Zhang Y. Spatial planning strategy for "low carbon cities" in China. Urban Planning Forum. 2008;6: 57-64. Available from: http://en.cnki.com.cn/Article_en/CJFDTotal-CXGH200806015.htm

[41] Chen J, Yang ST, Li HW, Zhang B, Lv JR. Research on geographical environment unit division based on the method of natural breaks (Jenks). International Archives of the Photogrammetry, Remote Sensing and Spatial Information Sciences. 2013;XL-4/W3: 47-50. Available from: https://www.int-arch-photogramm-remote-sens-spatial-inf-sci.net/XL-4-W3/47/2013/isprsarchives-XL-4-W3-47-2013.pdf

[42] Hangzhou Bureau of Statistics. 2016 Hangzhou Statistical Yearbook. Available from: http://tjj.hangzhou.gov.cn [Accessed 23 September 2016].

[43] Yin J. Study on characteristic of concentration and guidance of resident's activity. Dissertation. Tongji University, Shanghai, China; 2017.

[44] Tan J, Xu R. 2009. Analysis of multi-factors influencing trip chain buildup. Journal of Tongji University (Natural Science). 2009;37: 1340-1344. Available from: http:// en.cnki.com.cn/Article_en/CJFDTotal-TJDZ200910013. htm

[45] Hensher DA, Reyes AJ. Trip chaining as a barrier to the propensity to use public transport. Transportation. 2000;27(4): 341-361. DOI: 10.1023/A:1005246916731 